\title{
A Comparative Ecological Assertion in the Poems of Agha Shahid Ali and Sylvia Plath
}

\author{
Aadil Muzafar Pala \\ Ph.D. Research Scholar \\ Department of Languages and Comparative Literature \\ Cenral University of Punjab \\ Bathinda, Punjab, India \\ aadilmuzafar@hotmail.com
}

Dr. Zameerpal Kaur

Associate Professor

Department of Languages and Comparative Literature

Cenral University of Punjab

Bathinda, Punjab, India

zameersandhu@gmail.com

\begin{abstract}
The serious ecological crises like air pollution, acid precipitation, global warming, deforestation, and loss of biodiversity have engulfed our planet earth. Ecocriticism became very much acclaimed critical approach in the 1980's after Feminism and Post-colonialism, and developed, with attention from scholars of various fields, in different countries into a separate subject. In the application of Ecocriticism to the study of all forms of literary works it shows the ideas and thoughts that prove helpful in dealing with the relationship between man and nature, and also contribute to the cause of environmental preservation.
\end{abstract}


Keywords: Ecopoetics, Ecopsychology, Nature, Sensory Response, Sensous Poesis

Ecopoetics and contemporary poetry possess the primary responsibility of the cultivation of an environmental imagination in order to make it relevant and variable. In other words, it gives rise to some questions like, how shall we 'live' in a poem? To what use, in both practical and transcendent terms, do we put it? How do our uses of and beliefs in language evident in the poem parallel our uses and beliefs for the environment? What is the nature of poetic form, and how does it help us think and be, and relate ethically to where we live? Further, how is that poetic form an enactment of the things and processes of nature itself? A poem must provide a relevant landscape to our experience if it is a horizon. As a matter of perception, it should provide convincing proof that the language plays a fundamental role with the world upon examination, and its capacity to construct a space that can be made a habitat.

Like other arts, poetry is also an art of creation. The poet actually lives in an imaginary world and presents things as he/she imagines them and at times makes them more comprehensible, beautiful and creative than they can be seen by an ordinary person. A poet creates all together a new world, it is a matter of fact that the topic of poetry generally revolves round animated sentiments. The poets preserve the past incidents and events through the power of poetry.

Every poem has its value in human experience regardless of school. It is a piece of art to be looked at very closely, it is something of use very flexibly and pragmatically. All the poetic theories are of the consensus that the poem always remains the central evidence of understanding. The understanding establishes in that species of animal man which lives in contact with the world: "because experience is the fulfillment of an organism in its struggles and achievements in a world of things, it is art in germ" (Dewey 19). 
Primarily or secondarily all poems refer to a visible world and hence are landscape poems. The poem begins at some point and is either of nature or of mind. Poems are being formed for particular reasons that are to escape from the ugliness and boredom of daily life, or an assertion of the unexciting dignity. The poem is a pious kind of persuasion as is our most intimate belief of articulation. The poems sometimes meet our expectations to convince the world's chaos and divinity and at other times they fail to do so. No matter what our beliefs are, a poem's meaning seems to be driven by the possibility of language to create true relations between things and names. Language expresses an intrinsic purpose, that the shift of words and usage does not affect the accuracy. The deep structure plays an important role to retain a true and meaningful presence of the form. The philosopher George Steiner puts it plainly:

. . . any coherent understanding of what language is and how language performs, that any coherent account of the capacity of human speech to communicate meaning and feeling is, in the final analysis, under- written by the assumption of God's presence ... the experience of aesthetic meaning in particular, that of literature, of the arts, of musical form, infers the necessary possibility of this "real presence." (Steiner, 3)

This work will be a comparative textual analysis of the poetic works of Agha Shahid Ali and Sylvia Plath with the focus on the assertion of ecological concerns and their projection.

Agha Shahid Ali is known particularly for his skillful allusions to European, Urdu, Arabic and Persian literary traditions, Ali's poetry collections revolve around both thematic and cultural poles. Amardeep Singh has described Ali's style as 'ghazalesque,' (Singh) referring to Ali's frequent use of the form as well as his blending of the rhythms and forms of the Indo-Islamic tradition with a distinctly American approach to storytelling. Most of his 
poems are not abstract considerations of love and longing. Though Ali began publishing in the early 1970s, it was not until A Walk Through the Yellow Pages (1987) that he received widespread recognition. This book has been considered as a surreal world of frightening, fantasy, inaptness, wild humor, and the bizarre. Although the existential anxieties have their source in problems of growing up, leaving home, being a migrant, and the meeting of cultures, the saying is American and contemporary. Ali's next book, A Nostalgist's Map of America (1991), relates a series of travels through landscapes often blurred between his current American home and memories of his boyhood in Kashmir. King Bruce contended that such mind links past and present, America and India, Islamic and American deserts, American cities and former American Indian tribes, modern deserts and primitive oceans. There is a highly profiled language of color, paradoxes, oxymora, and other means to lift the poems into the lyrical and fanciful.

Nature has long played an important role in American migration poetry, it is being used as a symbol showing people's attachment to their place of home or for the migrant's sense of being uprooted. However, in recent poems of movement, nature matters in a more immediate environmental sense in terms of exploring people's geographical movement in relation to their perspectives on the natural world and to particular kinds of human-nature interaction. Such poems frequently engage the environmental issues of the migration of humans by way of comparing the present conditions of high standards of global world to the past ways of being close to land.

Agha Shahid Ali has contrasted the loss in human lives with the loss in the environment. In the poem Snow on the Desert, Ali recollects that the impact of nature and its purity is so deep on poet's mind that he can see his past in the eyes of natural entities. In the very outset of this poem he says:

So when I look at the sky, I see the past? 
yes, yes, he said. Especially on a clear day.

These lines show the deeply bonded and reciprocal relationship between nature and humans which makes human minds to think about the past and this thinking perhaps answers the questions like who we are?, how we grow?, and how we suffer?. Ecocritics termed this concept as Ecopsychology.

Later in this particular poem the tone becomes a bit melancholic and Ali seems to be lamenting on some kind of loss in his life while he proclaims in the same poem:

... it was, like this turning dark

of fog, a moment when only a lost sea

can be heard, a time

to recollect

every shadow, everything the earth was losing,

a time to think of everything the earth

and I had lost, of all

that I would lose,

of all that I was losing. (Ali, The Veiled Suite 164)

These lines clearly show that Ali is lamenting some loss in his life and he tries to juxtapose the loss in his life with the loss in the environment. He has used environmental imagery time and again in his poetic collection in order to reveal the ragged condition of what environment has become in present scenario. Here Ali realises the connection between humans and nature and finds it healing for both to work on grief and despair about environmental action and sustainable lifestyles. It is an Ecopsychological approach that includes both the psychological and the environmental reconnection.

In Snow on the Desert, the speaker reflects on the light from the sun and the stars, minutes old and millions of years old, offering a glimpse of what once was but is now gone: 


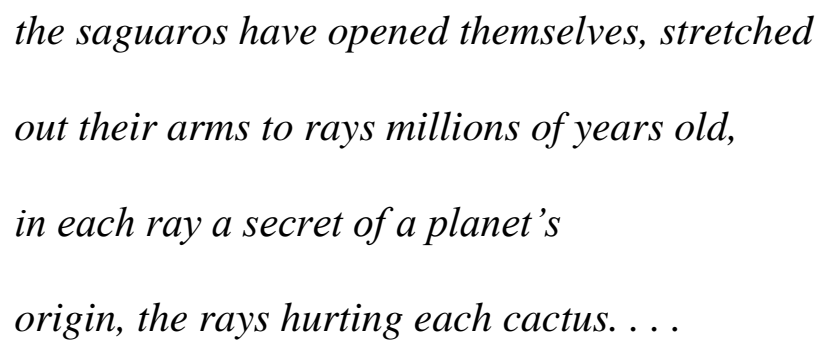

The expansive view leads us to wonder if, in the larger scheme, we are the survivors or the lost ones. Were the origins of these rays lost to time, or are we, rather, at a remote point in space and history? These lines again throw light on the concept of Ecopsychology.

In the poem I See Chile in My Rearview Mirror Agha Shahid Ali highlights his being one with nature and shows how man nature relationship directly affects each other, he writes:

\author{
I see Peru without rain, Brazil \\ without forests - and here in Utah a dagger \\ of sunlight: it's splitting-it's the summer \\ solstice-the quartz center of a spiral. \\ Did the Anasazi know the darker \\ answer also-given now in crystal \\ by the mirrored continent?
}

(Ali, The Veiled Suite 161)

The persecution of innocent civilians is juxtaposed against environmental destruction: global warming, deforestation, irresponsible water management, and the nuclear threat. In an interview with Rehan Ansari and Rajinderpal S. Pal, Ali reflects on how his parallel narrations of "the death of a friend ... the death of tribes, the death of landscapes and the death of a language ... create a density', (Ansari and Pal), which enables the aestheticising of "big subject matter" (Klenotic) without falling into "facile" political or maudlin rhetoric.

This poem clearly indicates that reverence of life is our guiding value which is one of the key tenets of the concept of Ecophilosophy. It also shows our violent and selfish attitudes 
towards fellow humans, and our widespread abuse of the environment. We kill our fellow beings to meet our own filthy and short lived ends and we cut forests and destroy nature again to fulfill our worldly desires. This action is totally condemned by ecocritics who explained its merits and demerits by using a term called 'Ecophilosophy'.

Agha Shahid Ali has given a vivid picture of the importance of streams and rivers in his poem Desert Landscape, and also says that these natural entities are the main sources of energy and if there is any sort of halt in their function the whole world will change into a desert. In this poem he talks about rain in a desert that is hope. He says:

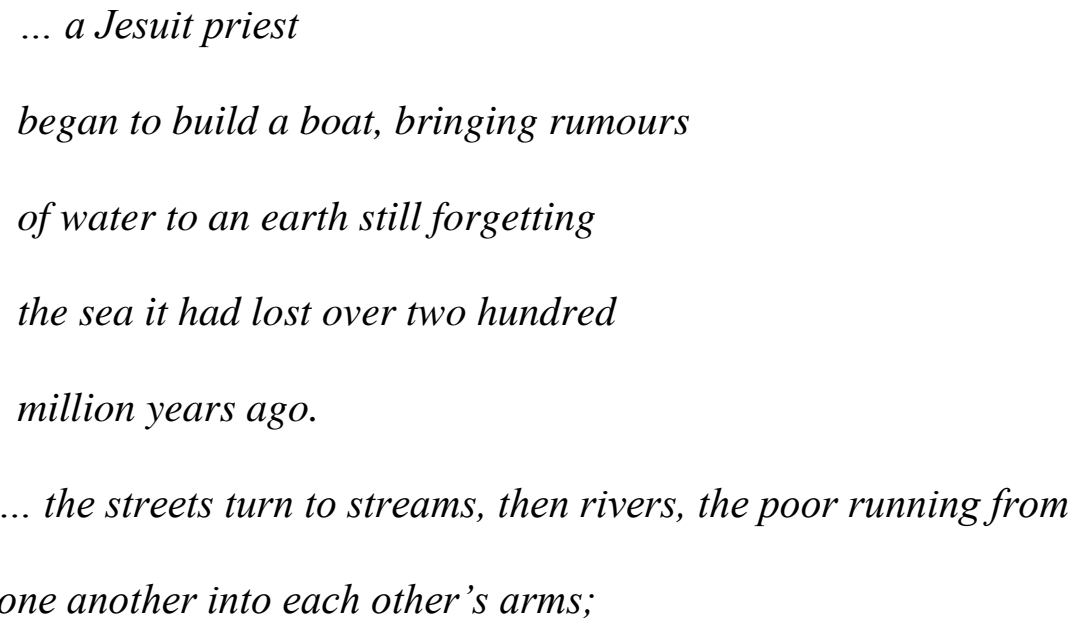

(Ali, The Veiled Suite 160)

In this poem Ali considers earth as barren both moral and in humanistic perspective, where people have lost hope like in a desert there is no hope of rain and he is very optimistic while saying that the time will come when there will be rain in the desert and all dreams will be fulfilled. The streets will be changed into streams and rivers, but it will come in abundance and will wash away everything that comes its way. The mountains will catch fire and everything will get vanished. This can be viewed as revenge from nature to mankind for destroying it in many ways. In this poem Ali projects that our chief objective should be to fight against the causes that are responsible for natural disasters like pollution and resource depletion, for the sake of the betterment of humans on earth. This is a thought put forward by 
ecocritics which they named as Shallow Ecological Movement. This proportion is clearly embedded in the above mentioned poem. These lines also comment on the usefulness of earth and Natural resources for human beings, which again is an attribute of Deep Ecology Movement.

Sylvia Plath has used nature as a recurrent theme in her poetic work, it is that lucrative force in her poetry which is not always predictable, but encourages her creative ability. Plath's poetry is filled with allusions and images of nature. She often evokes natural entities like sea and the fields to great effect. The sea is usually associated with her father, it is powerful, unpredictable, mesmerising and dangerous. An image of the sea is also used at many other places where it suggests a terrible sense of loss and loneliness. Plath's formal craft, her use of sensuous poesis as a response to her environmental concerns and sympathies make her an ecological poet of great importance.

Above all, Sylvia Plath's writing is sane? and I mean sane in at least two senses, neither of which in the least concerns Plath's own mental state. First, Plath's writing is sane in its argument and subject matter. Insistently, the writing concerns itself with real political and material issues, with "definite situations".... Second, the writing is sane in so far as it is controlled, methodical, and carefully wrought? a circumstance to which Plath's manuscripts in the archives testify. Both of these senses of sanity are the very opposite of the myth of Sylvia Plath as mad, depressed and pouring out her distress in an ink of blood. (Brain, The Other Sylvia Plath, 37)

Tracy Brain declares Plath's treatment of nature something beyond mere romantic admiration to deal soberly with the vulnerability of the body to toxic pollution. Plath expresses the ecological idea that death is often linked to alienation from one's environment 
and fellow creatures, rather than being obsessed with death, whereas life requires interaction with one's environment and other beings. Plath can be categorized as an ecological poet for the reason of her concern about industrialization and the destructive consequences of modern, technologized life, which she expressed periodically in her journals:

"I dislike apartments, suburbs. I want to walk directly out my front door into earth and into air free from exhaust" (Plath, Johny Panic and the bible of dreams, 39).

She also concisely expresses this troubled attitude toward motorized modernity in the third stanza of "Private Ground":

Eleven weeks, and I know your estate so well

I need hardly go out at all.

A superhighway seals me off.

Trading their poisons, the north and south bound cars

Flatten the doped snakes to ribbon. (Plath, Crossing the Water, 36)

The poet is clear here by saying not only does modern technology, in the form of cars and the superhighway 'poison' the environment, but also it 'seals' the speaker off from the woods and natural beauty of her friend's property.

The Eco-Psychological aspect paves way to the sense of biological kinship with nonhuman nature and that also provides material for language through sound effects and other formal devices to explore the figurative and aural capacity to evoke the natural world in powerful ways. This aspect can be explored in the poetry of both the poets as Sylvia Plath in "Mushrooms" writes:

We are shelves, 
We are tables,

We are meek,

We are edible,

Nudgers and Showers,

Inspite of ourselves.

Our kind multiplies:

We shall by morning

Inherit the earth

Our foot is in the door.

(Plath, The Colossus, 18)

The effect of personification here is not the projection of human emotion onto nature, the mushrooms display no motivation in their combination of humility and determination, but rather a wise portrayal of the way, to human perception, mushrooms appear at an individual level to be harmless. Even botanically speaking, it takes a large collection of mushrooms, connected underground, to comprise an organism, no mushroom stands alone. Thus Plath's use of first person plural is not merely a poetic stance, it expresses an ecological fact.

Plath was indeed aware and concerned about the effects of nuclear fallout on humans and the environment, but there are also other, less foreboding reasons to consider Plath an ecological poet.

Conclusion

There are poems that address concerns associated with the broader field of the environmental humanities, such as environmental and social justice and others engage with the natural world with an emphasis on our sensory responses to it. Both these poets suggest an emphasis on individual experience, but at the same time shows the relationship between 
the individual experiences and the effect it has on readers' abilities to appreciate their immediate natural surroundings. 


\section{Works Cited}

Ali, Agha Shahid. The Veiled Suite. New Delhi: Penguin Books India Pvt. Ltd, 2010.

Print.

Barry, Peter. Beginning Theory: An Introduction to Literary and Cultural Theory.

Manchester: Manchester University Press, 2012. Print.

Brain, Tracy. The Other Sylvia Plath. New York: Routledge, 2014. Print.

Buell, Lawrence. The Future of Environmental Criticism: Environmental Crisis and Literary Imagination. Oxford: Blackwell , 2005. Print.

Clark, Timothy. The Cambridge Introduction to Literature and Environment. New York: Cambridge University, 2011. Print.

Dewey, John. Art as Experience. New York: Minton, Balch, 1934. Print.

Garrard, Greg. Eco-criticism. New York: Rutledge, 2012. Print.

Glotfelty, Cheryll. The Eco-criticism Reader: Landmark in Literary Ecology. Athens: University of Georgia, 2005. Print.

King, Bruce. Modern Indian Poetry in English. Oxford: Oxford University Press, 1987. Print.

Mishra, Santosh Kumar. "Paradigm of Longing: The Poetic World of Agha Shahid Ali". www.galaxyimrj.com. November 2013. Web. 05 February 2017.

Plath, Sylvia. Crossing the Water. New York: Harper and Row publishers, Inc., 1971. Print.

Plath, Sylvia. Johnny Panic and the bible of dreams. London. 1977. Print.

Plath, Sylvia. The Colossus: and other poems. London: Faber and Faber, 1960. Print.

Singh, Amardeep. "The Kashmir Standard”. www.wordpress.com. 21 May 2013.Web. 06 March 2017.

Steiner, George. Real Presences. Chicago: U of Chicago P, 1989. Print. 
Sumathy, U. Eco-criticism in Practice. New Delhi: Sarup Book Publishers, 2009. Print.

Tosic, Jelica. "Eco-criticism - Interdisciplinary Study of Literature and Environment." www.tandfonline.com. 2006. Web. 05 April 2017. 